DOI: https://doi.org/10.47405/mjssh.v6i3.680

\begin{tabular}{|c|c|}
\hline & Malaysian Journal of Social Sciences and Humanities (MJSSH) \\
\hline 32 & Volume 6, Issue 3, March 2021 \\
\hline 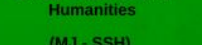 & e-ISSN : 2504-8562 \\
\hline & $\begin{array}{l}\text { Journal home page: } \\
\text { www.msocialsciences.com }\end{array}$ \\
\hline
\end{tabular}

\title{
The Impact of Financial Access on Female Labour Force Participation: Evidence from Panel Estimation
}

\author{
Khai Ying Eng1 ${ }^{1}$, Chee-Hong Law ${ }^{1}$, Yiing Jia Loke ${ }^{1}$ \\ ${ }^{1}$ Economic Section, School of Social Sciences, Universiti Sains Malaysia (USM) \\ Correspondence: Chee-Hong Law (cheehong@usm.my)
}

\begin{abstract}
This paper examines the relationship between financial access and economic empowerment among females, i.e., female labour force participation by testing a panel data of 51 countries ranging from 2004 to 2016. The number of bank branches and automated teller machines, both in thousand square feet and a hundred thousand adults, are applied as financial access indicators. The estimation method employed is the dynamic panel system generalized method of moment estimators. The control variables in the equation are the life expectancy, gross domestic product per capita, and female education enrolment. The results showed that bank branches have more noticeable impacts than automated teller machines in affecting the female labour force participation rate, implying that bank branches' services have a more substantial influence on women empowerment than automated teller machines. Furthermore, financial access indicators show a negative association with female labour force participation, probably due to female discrimination in financial access or the income effect caused by better financial access. Another possible reason is that the development policies could have bypassed women, as indicated by previous studies. To overcome this situation, governments could improve their financial service to ensure that financial access benefits women empowerment, including exploring the microfinance and special loans for female borrowers.
\end{abstract}

Keywords: financial access; female labour force participation; panel data; generalized system method of moments

\section{Introduction}

Women empowerment is frequently discussed under the Sustainable Development Goals and becomes a critical global challenge. The United Nations Development Program has illustrated that women's economic empowerment plays a vital role in eliminating gender-based discrimination and sustainable development. Furthermore, financially empowered women are more likely to improve the family's welfare (Karim, 2011). Previous literature has suggested that empowerment and resources are largely directed towards men, resulting in a deterioration of females' rights. The obstacles that hinder women's economic progress have to be addressed to achieve better women empowerment. The women's empowerment can be analyzed from economic, social, and political dimensions (Friedman, 1992; Malhotra and Schuler, 2002). According to Batliwala (1994), empowerment is achieved when people can access and gain control over the material, intellectual and ideological resources. On the other hand, economic empowerment is defined as the process where an individual's capacity to get involved and gain from growth processes will be increased in the ways that their contribution is being 
recognized and enjoys self-esteem. The benefits of growth will also be distributed in a fair manner (OECD, 2011).

This paper examines the impact of financial access on female economic empowerment, measuring by female labour force participation rate. The research will be conducted by testing a panel dataset that involves annual data in 51 countries from 2004 to 2016. Economic empowerment issues deserve more attention as women's economic empowerment is linked to human rights and social justice and critical for human development. Increasing women's economic empowerment through access and control on valued resources has positive implications on women's well-being and the next generation. Furthermore, it also enhances family planning and reduces gender discrimination in family resource allocation. Hence, women's economic empowerment will contribute to human capital and human capabilities, including their own. However, women's economic position is generally lower than men, typically in less developed countries (World Bank, 2014). In developing economies, most women need to depend on their resources and access to formal or semi-formal financial sources.

Furthermore, financial access could positively associate with the female labour force participation rate by enabling them to launch effective enterprises and reduce dependency on the local moneylender. Furthermore, having access to financial services enables women to improve their conditions and enhance their economic empowerment. However, not all findings substantiate the positive nexus between financial access and women economic empowerment. According to Pitt, Khandker and Cartwright (2006), women do not benefit from financial inclusion as development policies will bypass women and female has remained in a low status since generations. Besides, the income effect suggests that improve access to financial services will increase household income and allows women to allocate their time to other leisure activities rather than working.

Moreover, men tend to participate in labour markets more than women because women need to allocate time to activities that are not classically documented as 'economic activities' (Ortiz-Ospina \& Tzvetkova, 2018). Hence, financial access and economic development did not always benefit female participation in labour markets unless the opportunities cost of unpaid care work is reduced, higher matching with market work and better gender equality. Finally, job creation's nature and spatial distribution determine whether women can access jobs, particularly when social norms dictate how and where women can work.

The labour force participation rate is an important economic empowerment indicator as recommended by Lahoti and Swaminathan (2013), Chaudhary and Verick (2014), and Morsy and Youssef (2017). Figure 1 stated that the world female labour force participation rate dropped from 51\% in 2003 to $49 \%$ in 2012 and then stable. The relatively low labour force participation rate shows that women are not heavily involved in economic activity, indicating lower women empowerment. Moreover, the sharp decline from 2005 to 2012 might occur due to fierce gender competition among scarce jobs has increased (Kapsos, Silberman \& Bourmpoula, 2014). The global financial crisis may have also contributed to the decline. It is necessary to improve women's empowerment to change the present situation.

This paper contributes to the current literature by assessing whether access to finance is useful to boost women economic empowerment. This issue has not been explored extensively, especially by using secondary data. Hence, the outputs provide additional insights into the financial access-women economic empowerment nexus and are critical for some developing countries. Besides, our sample data has 51 countries which coverage wider than some other studies that focus on a country specifically. Furthermore, most of the papers investigate the impact of financial access to women economic empowerment in terms of microfinance. Unlike previous studies, this paper explores the nexus of access to finance and women economic empowerment using more formal finance institutions indicators. The following section presents the literature reviews. Section 3 describes the data and presents the hypothetical relationships. Section 4 covers the methodology, and the panel data results are discussed in Section 5. Finally, Section 6 concludes. 
Figure 1: World female labour force participation rate (\% of female population age $15+$ ) from 2003 to 2016

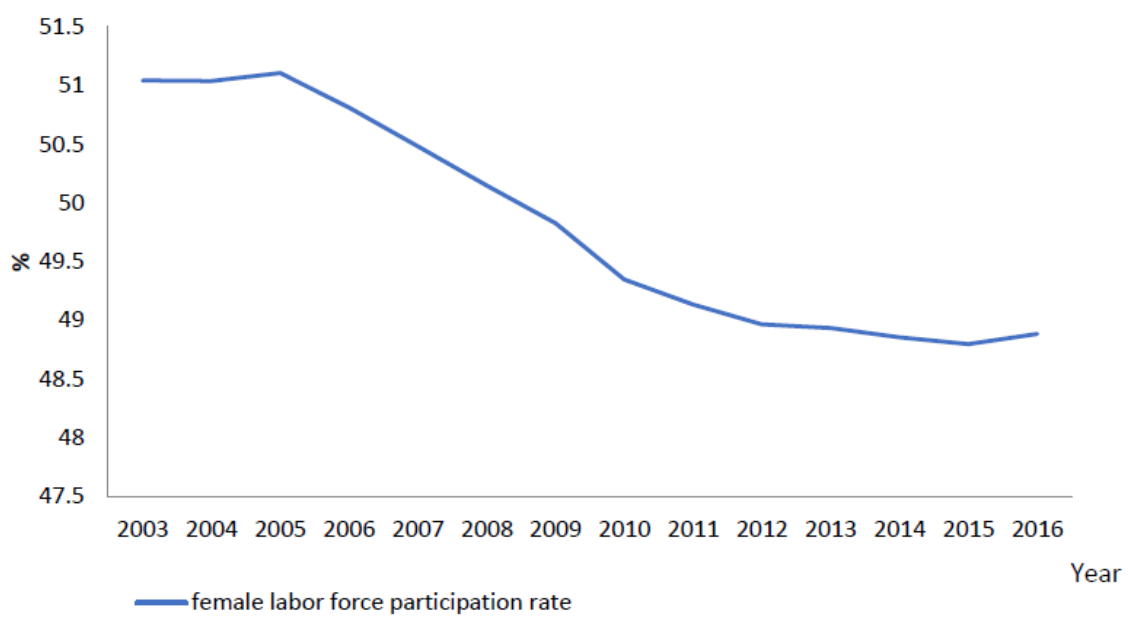

Source: World Development Indicator, World Bank

\section{Literature Review}

In general, financial access plays a vital role in enhancing women empowerment and leads to financial stability (Han \& Melecky; 2013; Swamy, 2014). Financial access improves women economic empowerment by allowing women to have more control over assets and their financial lives. Relaxing access to finance provides females with a safe and formal platform to save their earnings. Subsequently, the saving is utilised for their future investments and create a credit history (OECD, 2011). Department of Economic and Social Affairs (2009) adds that improving women access to finance is essential as women experience income discrimination, unequal divisions of labour and low control of economic resources. Additionally, providing credit accessibility to women leads to more investments in income-generating activities. Eventually, it increases incomes and improves household welfare (Holloway, Niazi, \& Rouse, 2017).

According to Cheston and Kuhn (2002), the accessibility to credit and involvement in incomegenerating activities enhance women's bargaining power in households, which builds up higher independence and strategic decision making. Besides, access to finance positively influences women empowerment because access to money will facilitate women in gaining control over the circumstances of their lives. Moreover, access to finance is a critical component of empowerment. Women traditionally have difficulty accessing credit due to limited land or assets ownership that can be used as collateral to secure loans

Kabeer (2005) reviewed and discussed previous findings of the impacts of access to finance on poor women's empowerment in South Asia. He finds that access to financial services empowers women by increasing economic productivity and leading to women empowerment. Furthermore, this also improves female social wellbeing. Besides, Siddik (2017) has conducted a structured questionnaire survey on 500 rural women living in the Kurigram and Gaibandha district in Bangladesh from January to February 2017. He suggests that financial inclusion improves women's economic empowerment by increasing their consumption power and social position.

In another paper, Hamida (2000) discusses how to empower women through access to finance in Tunisia. Access to finance is measured by the empirical observation of a micro-credit program. The result claimed that better access to finance could increase economic empowerment, and this betterment is crucial as it will initiate women empowerment in other aspects. Besides, Vaill (2003) theoretically analyses economic activity patterns that support women's economic empowerment in different 
geographic regions such as Africa, American, Asia and Europe to gain economic empowerment. The paper also discusses critical lessons from the Global Fund for Women's three-year Economic Opportunity Initiative ${ }^{1}$. He concluded that creating access to credit, skills training, and economic literacy enables women to successfully run their monetary affairs. These steps, according to Vaill, are the most effective interventions for women's economic empowerment. Moreover, Mayoux (2005) examines the relationship between financial inclusion and women social, political and economic empowerment based on secondary data in Asia, Africa and Latin America. The paper assumed that increasing women's access to financial services will enable women to decide about savings and credit use, gaining higher control in incomes, and improving economic empowerment at the individual level. The increased economic empowerment will further increase the well-being of women and also to social and political empowerment.

Not all findings substantiate the positive nexus between financial access and women economic empowerment as some research had the opposite view. According to Thabethe (2006), even though there are extensive business opportunities for women, many cannot exploit them because the financial markets have always been gender blind. Majority of the women have additional family and community responsibilities, creating the difficulty for women to startup and strengthen their enterprises. Witbooi and Ukpere (2011) employed a primary and secondary data to analyse the impact of access to financial services for women entrepreneur in South Africa. The study suggests that access to financial services continues to be racially defined in South Africa, and women suffer from cultural and economic disadvantage, which limited them from financial access.

Additionally, Rigol et al. (2016) discuss whether financial inclusion (measured by bank account ownership) can strengthen the female labour force participation in Madhya Pradesh, India. According to their analysis that involves a survey on 4500 eligible couple, financial inclusion alone did not improve the female labour force participation, even if women has a bank account and higher access to finance. Also, there is no observable impact on women's employment or earnings. The findings show that financial inclusion could strengthen the woman's bargaining power only if it changes outcome by easing saving constraints. It is line with the study of Callen et al. (2014), which proposed greater financial inclusion could impact labour supply only if easing saving constraints.

Besides, Pitt et al. (2006) explore the influence of financial access on empowerment using qualitative responses related to women's autonomy and gender relations within the household. These responses will, then, be used to reflect the empowerment index. The qualitative responses were collected from a household survey in rural Bangladesh from 1998 to 1999. The results indicate that, in theory, the accessibility to financial services among the women leads to greater women's empowerment because access to credit causes women to take a more active role in household decision making, having greater access to financial and economic resources, having greater bargaining power and gain greater freedom of mobility. However, the development policies have bypassed women and women remains low in economic status. Hence, women do not benefit from the development of financial inclusion.

In another paper, Ejaz (2007) highlights the major determinants of female labour force participation in Pakistan by deploying the Pakistan Social and Living Standards Measurement survey data from 2004 to 2005. The result shows that financial inclusion schemes do not help in boosting female labour force participation in Pakistan. The study suggests that some reason such as the high default rate on the part of borrowers, non-availability of donor might ease financial access schemes influence in female labour force participation. Furthermore, some research observed that financial inclusion programs did not uplift the economic status among poor women. Instead, it deteriorates the existing gender imbalances. For example, using the household survey data from Dharmapuri District, India, Holvoet (2005) linked the gender effects of subsidized credit programs and the lending technology for intra-household decision-making processes. The result showed that improvement in access to credit does not challenge the existing decision-making patterns, regardless of the credit receivers' gender. It also does not contribute to women empowerment unless credit transfers are specifically channelled to women.

\footnotetext{
${ }^{1}$ In 2002, the GlobalFund staff conducted a na naly sis of the three year initiative to identify the most effective strategies for alleviating poverty and a dvancing wom en's rights.
} 
Montgomery and Weiss (2011) explore the impact of financial inclusion on women empowerment in Pakistan by using the primary data from a household survey of nearly 3000 borrower and nonborrower households. The result found that female borrowers do not experience betterment significantly in empowerment after taking out a loan. In fact, they conclude that a supportive environment is needed to achieve the empowerment goal.

The implication of the financial market on female labour force participation can be observed by examining financial market development. Recently, Almiman, Pradikta and Altamimi (2020) employed panel data methods to investigate the determinants factors of women's job market participation in MENA countries from 1980 to 2014. The data has been collected from the World Development Indicator dataset and World Penn Table. The independent variables include financial development and education level. Financial development is measured by domestic credit to private sector percentage of GDP, while education level is proxy by years of schooling. The result presented a negative and insignificant coefficient of financial development in female labour participation equation. The finding coincides with the fact that most Middle East countries' financial sectors are underdeveloped and yet to unleash the positive effect of the financial sectors in the labour market, especially in the women's participation in the job market.

\section{Data Description and Hypothetical Relationships}

Table 1 below lists the name of 51 countries examined in the panel analysis here. A balanced panel data that consist of annual data from 2004 to 2016 are collected and estimated. This paper focuses on women economic empowerment, represented by the female labour force participation. Several studies have applied the same indicator to measure women economic empowerment status. For example, Ghani, Mani and O'Connell (2013) who examines the implications of political empowerment on women economic empowerment also use the female labour force participation to reflect women economic empowerment. Besides, Kabeer (2012) suggests that female labour force participation is directly linked with women economic empowerment. Chaudhary and Verick (2014) discuss India's women economic activities measured in female labour force participation rate. Lastly, Lahoti and Swaminathan (2013) use the female labour force participation rate to gauge women economic activity. The female labour force participation rate is available from the ILOSTAT database released by the International Labour Organization.

Table 1: Selected regions and countries in the study

\begin{tabular}{ll}
\hline Regions & Countries \\
\hline Europe & Austria, Belgium, France, Hungary, Iceland, Ireland, Czech Republic, Estonia, \\
& Croatia, Luxembourg, Belarus, Latvia, United Kingdom, Lithuania, Cyprus, \\
& Macedonia, Italy, Bulgaria, Denmark, Greece, Fiji, Albania
\end{tabular}

America Argentina, Brazil, Canada, Chile, Costa Rica, Ecuador, Belize, Dominican Republic, Honduras

Africa Algeria, Madagascar, Egypt, Burundi, Lesotho, Cameroon, Cabo Verde

Asia Japan, Korea, China, Bangladesh, Indonesia, Israel, Lebanon, Bhutan, Australia, Kazakhstan, Kyrgyz Republic, India, Iran

The status of financial access in this paper is identified by four indicators, namely the number of automated teller machines (ATMs) per thousand kilometres square, the number of ATM per hundred thousand adults, the number of bank branches per thousand kilometres square and the number of bank branches per hundred thousand adults. These data are available in the Financial Access Survey (FAS) 
database published by the International Monetary Fund (IMF). The FAS database collects annual data on indicators that track financial access, providing extensive coverage of 152 time-series data covering 47 financial indicators. These time series data are grouped by the geographic outreach and the use of financial services. Previous studies such as those of Degryse and Ongena (2005), Sarma (2008), Sophastienphong and Kulathunga (2008) have employed ATMs and bank branches to indicate the degree of access to finance in their study. Several control variables are included in the women economic empowerment equations to improve the estimated coefficients' causal interpretation and avoid omitted variables bias. These variables are female secondary school enrolment rate (percentage), life expectancy (years) and gross domestic product per capita (current value US Dollar). These variables are also typically included in the labour force participation equation (e.g. Alexander, 2007; Dhakal \& Nawaz, 2009). These data are obtained from the World Bank database.

Based on the literature discussed in the last section, the coefficient sign of the financial access on the labour force participation rate among women is expected to be ambiguous. Education level is expected to have a positive relationship with women economic empowerment because education confronts women traditional role and enables women to respond to the challenges and improve the ability to join the job market. Previous studies have also emphasized that increased schooling contributes to women empowerment and improves women's opportunities in the labour market because education increases market wages (Birdsall \& Griffin, 1988). Psacharopoulos and Tzannatos (1989) add that education is a potential booster of the female labour force participation in developing countries and controlling education variable is more efficient than controlling other variables.

According to Jayachandran and Lleras-Muney (2009), life expectancy is assumed to positively influence women's economic empowerment since an increase in life expectancy creates more years of education to girls (relative to boys). It indirectly improves girl competitive power in the labour market. They also mention that education could improve women's relative welfare by reducing their chance of dying at childbirth. With longer life expectancy, women are expected to achieve higher education and enhance their economic empowerment. Moreover, an increase in the gross domestic product (GDP) per capita is expected to improve the economic right and women economic empowerment. Kottis (1990) claims that economic development's acceleration pushes the demand for female labour in the market. Therefore, the probability of entering the labour market for females will rise, bringing a positive implication to female labour force participation rates.

However, some studies hold the opposite view. For example, Karshenas and Moghadam (2001) find that in the Middle East and North Africa (MENA) countries, higher GDP per capita allows women to stay home and contribute less to the labour market. The similar finding also reported by Baslevent and Onaran (2003) in a study in Turkey. Finally, using panel data from World Bank data from 1990 to 2008, Aboohamidi and Chidmi (2013) investigate the major determinants of female labour force participation in Pakistan and some MENA countries. The result showed that women in countries with higher GDP per capita and more conservative cultures tend to work less and afford to stay home. Hence, when the GDP per capita increase, female labour force participation decreases. They explain that this is due to the low wage effect and high opportunities cost of working outside.

\section{Methodology}

This paper estimated the following dynamic equation to achieve the objective.

$$
L F F_{t}=a_{1}+a_{2} L F F_{t-1}+a_{3} L F A_{t}+a_{4} L E_{t}+a_{5} E D U F_{t}+a_{6} L G D P C_{t}+\mathrm{\eta}+\varepsilon_{i t}
$$

where $L F F$ is the women economic empowerment that proxied by the female labour force participation rate, $L F A$ is the natural logarithm of financial access indicators. The baseline model estimates the impact of ATM thousand per square kilometres, $L E$ is life expectancy, and $E D U F$ refers to the female secondary school gross enrolment (percentage). $L G D P C$ is the natural logarithm of gross domestic product per capita (current USD). Finally, the $\eta$ and $\varepsilon$ indicate the unobserved countryspecific effect independently and identically distributed error team, respectively. 
Estimation wise, the system generalized method of moments (S-GMM) estimator developed by Blundell and Bond (1998) is applied. Used to estimate a dynamic panel model, the S-GMM consists of two equations, i.e. differenced and level equations. It leads to the inclusion of additional moment conditions created by the initial observations' stationary conditions. The stationarity condition is due to the dependent variable's persistence. This additional moment is absent in the difference GMM; the difference GMM only contains the moment conditions for the level equation. Instruments variables are applied in the model to overcome the endogeneity bias and serial correlation in a dynamic panel model. In particular, the instrument for the difference and level equation is the level of the endogenous variable and the first-differenced of the endogenous variables, respectively. In this paper, the maximum of two lag of the dependent variable is utilised as the instrument variables. Although the $\mathrm{S}$ GMM estimators improve estimation efficiency compared with the difference GMM estimation, it also leads to the possibility of instrument proliferation that will create misleading results. This paper avoids instrument proliferation by limiting the number of lags used as instruments. The rule of thumb is that the number of lags should be lower than the number of cross-sectional units. ${ }^{2}$

Moreover, the Sargan test and the autoregressive (AR) autocorrelation test are applied to test the instruments' validity and confirm the absence of the second-order autocorrelation in the residuals, respectively. The null hypothesis of the Sargan test is that the instruments are valid. On the other hand, the AR autocorrelation tests the null hypothesis of no autocorrelation. The result's robustness is confirmed by testing the model with different combinations of control variables and applying another three financial access indicators. These indicators are the number of ATM per ten thousand adults, bank branches per ten thousand square kilometres, and bank branches per ten thousand adults. ${ }^{3}$ Finally, the Cook's Distance Outlier test (Cook, 1977) is used to detect outliers that may influence the estimation result and the regression's slope; these outliers are excluded from estimations.

\section{Result Discussions}

The estimation results of the baseline model are presented in Table 2. The other three models that examine the other three financial access indicators are, otherwise, are presented in Table 3 to Table 5. By testing different financial access indicator, the robustness of the result can be tested. The model performance is reasonably well, as indicated by the Sargan and AR(2) autocorrelation test. In particular, the p-values of the Sargan test are above 0.05 in most models except for the model 1 in Table 2 to Table 4 . Nonetheless, the rejection AR(1) in those models is rather weak (p-value is close to 0.05). Hence, this paper assumes that the identifications imposed in the estimations are valid. Furthermore, the second-order AR autocorrelation test (AR2) failed to reject the null hypothesis of no second-order autocorrelation. In contrast, the first-order AR autocorrelation test (AR1) shows the opposite conclusion.

The estimation results presented in Table 2 show the persistent effect of financial access on the female labour force participation rate is confirmed by the coefficient of lagged LFF that close to one and statistically significant. The number of ATM per thousand-kilometre square has a negative and statistically significant impact on female labour force participation. In other words, this paper rejects the positive implication of financial access to women economic empowerment. This negative effect is in line with the literature review's argument that easing financing constraints does not benefit women's economic empowerment or increase female labour force participation (e.g. Ejaz, 2007; Montgomery \& Weiss, 2011; Almiman et al., 2020). This result is in line with the conclusion of Witbooi and Ukpere (2011) that suggest women suffer from cultural and economic disadvantage, which limited them from financial access. Theoretically, the accessibility to financial services helps women to gain greater bargaining power and leads to greater women's empowerment; however, the development policies

\footnotetext{
2 The Stata code "xtdpdsys" is used for the estimation.

${ }^{3}$ The robustness of the result is also confirmed by using the non-overlapping two-year average data and estimating all models by using the maximum one lag of dependent variable as the instrument variable. The results in general concurs with the impact of financial access on female labour force participation rate discussed here but are not reported here to conserve space.
} 
have bypassed women, and they stay in a position where they were since generations, so women did not benefit from financial access policy (Pitt et al., 2006).

Furthermore, Holvoet (2005) highlight that some studies indicate that access to finance improves women empowerment only if certain criteria appear, such as the credit transfer is specifically allocated to female. Another alternative reason for the negative sign of financial access is the income effect. According to Anyanwu and Augustine (2013), economic could increase household income, allowing women to enjoy more leisure time. Subsequently, the female participation in the labour market will be lower. This paper suggests that financial access could be a facilitator for economic growth, leading to the negative association between financial access and female labour force participation rate, which is detected here.

Table 2 also shows a positive and statistically significant impact from life expectancy on female labour force participation rate. The result is consistent with the hypothesis where life expectancy influences women economic empowerment positively. Besides, the secondary school enrolment level has an insignificant negative influence on female labour force participation. In other words, the female school enrolment level in Table 2 cannot find concrete evidence to link the impact of education on female labour force participation. Similarly, Klasen and Pieters (2013) suggested that the positive effect of higher education on female labour force participation rate is low. It can be due to the lack of job opportunities for well-educated women, or women have pursued higher education to gain high marriage market returns ${ }^{4}$ but have not participated in the labour market.

Table 2: Female Labor Force participation equation with the number of ATM per 1000km²

\begin{tabular}{|c|c|c|c|}
\hline \multicolumn{4}{|c|}{ Dependent variable: female labour force participation rate } \\
\hline & Model 1 & Model 2 & Model 3 \\
\hline The lagged of LFF & $\begin{array}{l}0.9749 * * * \\
(0.0044)\end{array}$ & $\begin{array}{l}0.9613 * * * \\
(0.0061)\end{array}$ & $\begin{array}{l}0.9593 * * * \\
(0.0059)\end{array}$ \\
\hline LFA & $\begin{array}{l}-0.1570 * * * \\
(0.0259)\end{array}$ & $\begin{array}{l}-0.1310^{* * * *} \\
(0.0361)\end{array}$ & $\begin{array}{l}-0.1529 * * * \\
(0.0399)\end{array}$ \\
\hline LE & $\begin{array}{l}0.1179 * * * \\
(0.0116)\end{array}$ & $\begin{array}{l}0.1119 * * * \\
(0.0107)\end{array}$ & $\begin{array}{l}0.1036 * * * \\
(0.0123)\end{array}$ \\
\hline EDUF & & $\begin{array}{l}-0.0009 \\
(0.0026)\end{array}$ & $\begin{array}{l}-0.0009 \\
(0.0024)\end{array}$ \\
\hline LGDPC & & & $\begin{array}{l}0.0760 \\
(0.0704)\end{array}$ \\
\hline Observations & 556 & 513 & 513 \\
\hline Number of countries & 50 & 47 & 47 \\
\hline $\begin{array}{l}\text { Number of } \\
\text { instruments }\end{array}$ & 45 & 46 & 47 \\
\hline Sargan (p-value) & 0.2166 & 0.4436 & 0.4240 \\
\hline AR (1) (p-value) & 0.0425 & 0.0674 & 0.0654 \\
\hline AR (2) (p-value) & 0.4098 & 0.5754 & 0.5814 \\
\hline
\end{tabular}

Note: $* * *, * *$ and $*$ indicates the significance level at $1 \%, 5 \%$ and $10 \%$. Time dummies included in our estimation but not presented to conserve space. LFA refers to the natural logarithm of financial access, LE refers to the life expectancy, EDUF refers to the female secondary school gross enrolment for female (percentage) and LGDPC is the natural logarithm of gross domestic product per capita.

Finally, the negative relationship between GDP per capita and female labour force participation rate in the number of ATM per thousands kilometre square concurs with previous research such as Duflo (2012) and Lincove (2008). In detail, Duflo (2012) argues that economic development is not enough to

\footnotetext{
${ }^{4}$ Klasen and Pieters (2013) claimed that female education expansion is driven by expected marriage market returns rather than labour market returns as higher women's education more likely to marry a "high quality" spouse.

Moreover, women's education could contribute to husbands"e social status directly even in absence of labor market returns.
} 
ensure women's empowerment and equality on its own and gender gap might still exist. Lincove (2008) concluded that there is a negative relationship between economic growth and female labour force participation, that is, economic growth hinders female labour force participation.

Table 3 to Table 5 contains the output of the estimation of other financial access indicators. Importantly, the negative linkage between financial access and female labour force participation is also found in other indicators; all of them are statistically significant, except for the estimations that use the number of bank branch per thousand kilometres square (See Table 4). These results provide partial evidence to substantiates the conclusion about the implication of financial access measured by ATM per thousand kilometres square in Table 2. For the life expectancy, the result from Table 2 to Table 4 show a positive and statistically significant impact on female labour force participation rate, and it is consistent with our hypothesis. The statistical insignificance of education is also found in Table 3 to Table 5, although the coefficient sign is positive in these tables. Finally, the coefficient sign of GDP per capita is inconsistent in these tables. Furthermore, the coefficient is insignificant, in line with the conclusion found in Table 2 .

Table 3: Female labour force participation equation with the number of ATM per 100,000 adults

\begin{tabular}{llll}
\hline Dependent variable: & $\begin{array}{l}\text { female labour force } \\
\text { Model 1 }\end{array}$ & $\begin{array}{c}\text { participation rate } \\
\text { Model 2 }\end{array}$ & Model 3 \\
\hline The lagged of LFF & $0.9800^{* * *}$ & $0.9533^{* * *}$ & $0.9518^{* * *}$ \\
& $(0.0046)$ & $(0.0069)$ & $(0.0069)$ \\
LFA & $-0.1794 * * *$ & $-0.1063^{* * *}$ & $-0.1245^{* * *}$ \\
& $(0.0295)$ & $(0.0385)$ & $(0.0470)$ \\
LE & $0.1364 * * *$ & $0.1263^{* * *}$ & $0.1171^{* * *}$ \\
& $(0.0109)$ & $(0.0098)$ & $(0.0148)$ \\
EDUF & & 0.0006 & 0.0005 \\
& & $(0.0030)$ & $(0.0030)$ \\
LGDPC & & & 0.0724 \\
& & & $(0.0678)$ \\
Observations & 568 & 525 & 525 \\
Number of countries & 50 & 48 & 48 \\
Number of & 45 & 46 & 47 \\
instruments & & & \\
Sargan (p-value) & 0.1904 & 0.3488 & 0.3831 \\
AR (1) (p-value) & 0.0424 & 0.0661 & 0.0658 \\
AR (2) (p-value) & 0.3974 & 0.5837 & 0.5868 \\
\hline
\end{tabular}

Note: $* * *, * *$ and $*$ indicates the significance level at $1 \%, 5 \%$ and $10 \%$. Time dummies included in our estimation but not presented to conserve space. LFA refers to the natural loga rithm of financialaccess, LE refers to the life expectancy, EDUF refers to the female secondary school gross enrolment for female (percentage) and LGDPC is the natural logarithm of gross domestic product per capita.

\section{Conclusions}

This paper examines the impact of financial access on female labour force participation in 51 developed and developing countries, after controlling for several control variables. It covers the annual data from 2004 to 2016. Examining the impact of financial access on women's economic empowerment is critical to achieving gender equality and sustainable development. Furthermore, it is commonly believed that improving women economic empowerment is linked to human development and social justice. Although it is widely accepted that financial access plays a vital role in enhancing women empowerment, this paper's findings showed that female participation in the labour market reduces when financial access improves. The life expectancy shows a consistent positive significant nexus with female labour force participation rate. At the same time, the GDP per capita holds a negative relationship in four financial access indicators. Finally, education shows an insignificant 
DOI: https://doi.org/10.47405/mjssh.v6i3.680

result with female labour force participation. The robustness estimations, estimated by another three financial access indicators, mostly support the baseline estimations' conclusions.

Table 4: Female labour force participation equation with the number of bank branches per $1000 \mathrm{~km}^{2}$

\begin{tabular}{|c|c|c|c|}
\hline \multicolumn{4}{|c|}{ Dependent variable: female labour force participation rate } \\
\hline & Model 1 & Model 2 & Model 3 \\
\hline \multirow[t]{2}{*}{ The lagged of LFF } & $0.9723 * * *$ & $0.9651 * * *$ & $0.9694 * * *$ \\
\hline & $(0.0050)$ & $(0.0048)$ & $(0.0060)$ \\
\hline \multirow[t]{2}{*}{ LFA } & -0.0257 & 0.0009 & 0.0160 \\
\hline & $(0.0340)$ & $(0.0225)$ & $(0.0267)$ \\
\hline \multirow[t]{2}{*}{ LE } & $0.1166 * * *$ & $0.1051 * * *$ & $0.1072 * * *$ \\
\hline & $(0.0102)$ & $(0.0096)$ & $(0.0147)$ \\
\hline \multirow[t]{2}{*}{ EDUF } & & 0.0007 & 0.0011 \\
\hline & & $(0.0026)$ & $(0.0027)$ \\
\hline \multirow[t]{2}{*}{ LGDPC } & & & -0.0723 \\
\hline & & & $(0.0742)$ \\
\hline Observations & 552 & 510 & 510 \\
\hline Number of countries & 50 & 48 & 48 \\
\hline $\begin{array}{l}\text { Number of } \\
\text { instruments }\end{array}$ & 45 & 46 & 47 \\
\hline Sargan (p-value) & 0.2288 & 0.4470 & 0.6463 \\
\hline AR (1) (p-value) & 0.0473 & 0.0703 & 0.0714 \\
\hline AR (2) (p-value) & 0.3391 & 0.4589 & 0.4474 \\
\hline
\end{tabular}

Note: $* * *, * *$ and $*$ indicates the significance level at $1 \%, 5 \%$ and $10 \%$. Time dummies included in our estimation but not presented to conserve space. LFA refers to the natural loga rithm of financial access, LE refers to the life expectancy, EDUF refers to the female secondary school gross enrolment for female (percentage) and LGDPC is the na tural logarithm of gross domestic product per capita.

The negative association between financial access and women economic empowerment is somehow unexpected. This paper offers two possible explanations. On the one hand, the women could face more disadvantage in the job market as they face discrimination in accessing the financial service. On the other hand, the income effect could reduce women's need to join the labour market. Based on the conclusion, one policy implication is that the government should review bank branches and ATMs' current role in driving financial access to ensure the positive spill-over from financial access to women. It includes the financial products that match the female borrowers in particular. Furthermore, the financing tools that support job creation and female entrepreneurship such as microfinance could be promoted instead of depending on the formal financial institutions. One of this paper's caveats is that it does not differentiate in developed and developing countries due to data availability limitation. Besides, the selection of the financial indicators here could be questionable. However, the indicators here are believed to be appropriate as it has been used in previous studies to indicate financial access. Future research could have explored the impact of cultural and institutional factors in the finance access-labour force participation nexus.

Table 5: Female labour force participation equation with the number of bank branches per 100,000 adults

\begin{tabular}{llll}
\hline \multicolumn{2}{l}{ Dependent variable: } & $\begin{array}{l}\text { female labour force participation rate } \\
\text { Model 1 }\end{array}$ & $\begin{array}{ll}\text { Model 2 } \\
\text { Model 3 }\end{array}$ \\
\hline The lagged of LFF & $0.9639^{* * *}$ & $0.9218^{* * *}$ & $0.9268^{* * *}$ \\
& $(0.0057)$ & $(0.0089)$ & $(0.0090)$ \\
LFA & $-0.1778^{* * *}$ & $-0.2344^{* * *}$ & $-0.1866^{* *}$ \\
& $(0.0681)$ & $(0.0630)$ & $(0.0743)$ \\
LE & $0.1152^{* * *}$ & $0.1103^{* * *}$ & $0.1186^{* * *}$ \\
& $(0.0087)$ & $(0.0051)$ & $(0.0184)$
\end{tabular}


Malaysian Journal of Social Sciences and Humanities (MJSSH), Volume 6, Issue 3, (page 259 - 271), 2021

DOI: https://doi.org/10.47405/mjssh.v6i3.680

\begin{tabular}{llll} 
EDUF & & $\begin{array}{l}0.0017 \\
(0.0029)\end{array}$ & $\begin{array}{l}0.0025 \\
(0.0028)\end{array}$ \\
LGDPC & & & -0.0751 \\
& & & $(0.0921)$ \\
& & & 504 \\
Observations & 546 & 504 & 46 \\
Number of countries & 49 & 46 & 47 \\
Number of & 45 & 46 & 0.5491 \\
instruments & & & 0.5069 \\
Sargan (p-value) & 0.3799 & 0.0888 & 0.5457 \\
AR (1) (p-value) & 0.0579 & 0.5521 & (p) \\
AR (2) (palue) & 0.4248 & & \\
\hline
\end{tabular}

Note: ***, ** and * indicates the significance level at $1 \%, 5 \%$ and $10 \%$. Time dummies included in our estimation but not presented to conserve space. LFA refers to the natural loga rithm of financial access, LE refers to the life expectancy, EDUF refers to the female secondary school gross enrolment for female (percentage) and LGDPC is the na tural logarithm of gross domestic product per capita.

\section{References}

Aboohamidi, A., \& Chidmi, B. (2013). Female Labor Force Participation in Pakistan and Some MENA Countries. Paper presented at the Southern Agricultural Economics Association Annual Meeting, Orlando, FL. Abstract retrieved from file://C:/Users/k/Downloads/SAEAAboohmaidi_Chidmi\%20(1).pdf

Alexander A. C. (2007). Empowering Women: The Role of Economic Development, political culture and institutional design in the world societies (CSD Working paper). https://escholarship.org/uc/item/4974t33n

Almiman, A. A., Pradikta, A. C., \& Altamimi, R. (2020). Factors Determining Female Labor Participation in Job Market in the Middle East and North Africa (MENA) Countries. Populasi, 28(1), 44-62.

Anyanwu, John C., \& Augustine, D. (2013). Gender Equality in Employment in Africa: Empirical Analysis and Policy Implications. African Development Review, 25(4), 400-420.

Baslevent, C., \& Onaran, O. (2003). Are Married Women in Turkey More Likely to Become Added or Discouraged Workers? Labour, 17(3), 439-458.

Batliwala, S. (1994). The Meaning of Women's Empowerment: New Concepts from Action. In G. Sen, A. Germain and L C. Chen (Eds.), Population Policies Reconsidered: Health, Empowerment and Rights (pp. 127-38). Boston: Harvard University Press.

Birdsall, N., \& Griffin, C. (1988). Fertility and Poverty in Developing Countries. Journal of Policy Modeling, 10(1), 29-55.

Blundell, R., \& Bond, S. (1998). Initial conditions and moment restrictions in dynamic panel data models. Journal of Econometrics, 87(1), 115-143.

Callen, M., De Mel, S., McIntosh, C., \& Woodruff, C. (2014). What are the Headwaters of Formal Savings? Experimental Evidence from Sri Lanka. (NBER Working Paper No. 20736). https://www.nber.org/papers/w20736.

Chaudhary, R., \& Verick, S. (2014, October). Female labour force participation in India and beyond. (ILO Working Papers). https://www.ilo.org/wcmsp5/groups/public/\%40asia/\%40robangkok/\%40sro-new_delhi/documents/publication/wcms_324621.pdf

Cheston, S., \& Kuhn, L. (2002). Empowering women through microfinance. In S. Daley-Harris (Ed.), Pathways out of poverty: Innovation in microfinance for the poorest familiars (pp. 67228). Bloomfield, CT: Kumarian Press

Cook, R. D. (1977). Detection of Influential Observation in Linear Regression. Technometrics, 19, 1518.

Degryse, H., \& Ongena, S. (2005). Distance, lending relationships and competition. The Journal of Financial, 60, 231-266. 
Department of Economic and Social Affairs (2009). World Survey on the Role of Women in Development: Women's Control over Economic Resources and Access to Financial Resources, including Microfinance. New York. Retrieved from http://undocs.org/en/A/64/93

Dhakal, T. N., \& Nawaz, F. (2009, December). Strategy for Improving Human Capital in Bangladesh and Nepal: Does it help for women empowerment. Paper presented at the Network of AsiaPacific Schools and Institutes of Public Administration and Governance (NAPSIPAG) Annual Conference Malaysia. Abstract retrieved from file:///C:/Users/k/Downloads/SSRNid2222532.pdf

Duflo, E. (2012). Women's empowerment and economic development. Journal of Economic Literature, 50(4), 1051-1079.

Ejaz, M. (2007). Determinants of female labour force participation in Pakistan an empirical analysis of PSLM (2004-05) Micro Data. Lahore Journal of Economics, 12, 204-235.

Friedman, J. (1992). Empowerment. The politics of an alternative development. Oxford: Basil Blackwell.

Ghani, E., Mani, A., \& O'Connell, S. (2013). Can political empowerment help economic empowerment? Women leaders and female labour force participation in India (Policy Research Working Paper 6675). http://documents1.worldbank.org/curated/en/655271468284122309/pdf/WPS6675.pdf

Hamida, E.B. (2000). Empowering Women through Microcredit: A case study from Tunisia. Paper presented at the MDF3: Civil Society Workshop, Cairo, Egypt. Abstract retrieved from http://www.endatamweel.tn/wp-content/uploads/2016/05/Empowering-Women-Through-MicroCredit-A-Case-Study-from-Tunisia.pdf

Han, R., \& Melecky, M. (2013). Financial inclusion for financial stability: Access to bank deposits and the growth of deposits in the global financial crisis (MPRA Working Paper No. 48338). Retrieved from https://mpra.ub.uni-muenchen.de/48338/

Holloway, K., Niazi, Z., \& Rouse, R. (2017). Women's Economic Empowerment through financial inclusion: a review of existing evidence and remaining knowledge gaps. New Haven, CT: Innovations for Poverty Action. Retrieved from https://www.povertyaction.org/sites/default/files/publications/Womens-Economic-Empowerment-Through-

Financial-Inclusion.pdf

Holvoet, N. (2005). The impact of microfinance on decision-making agency: evidence from South India. Development and Change, 36(1), 75-102.

Jayachandran, S., \& Lleras-Muney, A. (2009). Life Expectancy and Human Capital Investments: Evidence from Maternal Mortality Declines. Quarterly Journal Economics, 124(1), 349-398.

Kabeer, N. (2005). Gender Equality and Women's empowerment: A Critical Analysis of the Third Millennium Development Goal. Gender and Development, 13(1), 13-24.

Kabeer, N. (2012). Women's Economic Empowerment and Inclusive Growth: Labour Markets and Enterprise Development (SIG Working Paper 2012/1). Retrieved from https://www.idrc.ca/sites/default/files/sp/Documents\%20EN/NK-WEE-Concept-Paper.pdf

Kapsos, S., Silberman, A., \& Bourmpoula, E. (2014). Why is female labour force participation declining so sharply in India? (ILO Working Paper No. 10). Retrieved from https://www.ilo.org/wcmsp5/groups/public/---dgreports/--inst/documents/publication/wcms_250977.pdf

Karim, L. (2011). Microfinance and Its Discontents: Women in Debt in Bangladesh. MN: University of Minnesota Press

Karshenas, M., \& Moghadam, V. (2001). Female Labor Force Participation and Economic Adjustment in the MENA Region. The Economics of Women and Work in the Middle East and North Africa, 4, 51-74.

Klasen, S., \& Pieters, J. (2013). What Explains the Stagnation of Female Labor Force Participation in Urban India? (IZA DP Working Paper 7597). Retrieved from http://ftp.iza.org/dp7597.pdf

Kottis, A. P. (1990). Shifts Over Time and Regional Variation in Women's Labor Force Participation Rates in a Developing Economy. Journal of Development Economics, 33(1), 117-132.

Lahoti, R., \& Swaminathan, H. (2013). Economic development and female labour force participation in India (IIMB Working Paper No. 414). Retrieved from https://www.iimb.ac.in/sites/default/files/2018-07/WP_No._414_0.pdf 
Lincove, J. A. (2008). Growth, girls' education, and female labor: A longitudinal analysis. The Journal of Developing Areas, 41(2), 45-68.

Malhotra, A., \& Schuler, S.R. (2005). Women's empowerment as a variable in international development. Paper presented at the World Bank Workshop on Poverty and Gender: New perspectives. Abstract retrieved from https://www.academia.edu/17726621/Measuring_womens_empowerment_as_a_variable_in_int ernational_development

Mayoux, L. (2005). Women's Empowerment through Sustainable Microfinance: Rethinking Best Practice. Enterprise Development Impact Assessment Information Service. Retrieved from https://citeseerx.ist.psu.edu/viewdoc/download?doi=10.1.1.121.2948\&rep=rep1\&type=pdf

Montgomery, H., \& Weiss, J. (2011). Can commercially-oriented microfinance help meet the millennium development goals? Evidence from Pakistan. World Development, 39, 87-109.

Morsy, H. \& Youssef, H. (2017). Access to Finance: Mind the Gender Gap (EBRD Working Paper No. 202). Retrieved from file:///C:/Users/k/Downloads/WP_202\%20(1).pdf

OECD (2011, April). Women Economic Empowerment (OECD-DAC GENDERNET Issues Paper) Retrieved from http://www.oecd.org/social/gender-development/47561694.pdf

Ortiz-Ospina, E., \& Tzvetkova, S. (2018). Women's employment. Retrieved from https://ourworldindata.org/female-laborsupply?preview_id=13372\&preview_nonce=6d1f899c93\&_thumbnail_id=-1\&preview=true

Pitt, M. M., S.R. Khandker \& J. Cartwright (2006). Empowering women with microfinance: Evidence from Bangladesh. Economic Development and Cultural Change, 54, 791-831.

Psacharopoulos, G., \& Tzannatos, Z. (1989). Female labour force participation: An international perspective. The World Bank Research Observer, 4(2), 187-201.

Rigol, N., Pande, R., Field, E., Schaner, S., \& Moore, C. T. (2016, November). On Her Account: Can Strengthening Women's Financial Control Boost Female Labor Supply? (HBS Working Paper). Retrieved from https://www.hbs.edu/faculty/Pages/item.aspx?num=56847

Sarma, M. (2008, June). Index of financial inclusion (CRIER Working Paper No. 215). http://www.icrier.org/pdf/Working_Paper_215.pdf

Siddik, M. N. A. (2017). Does financial inclusion promote women empowerment? Evidence from Bangladesh. Applied Economics and Finance, 4(4), 169-177.

Sophastienphong, K., \& Kulathunga, A. (2008). Getting finance in South Asia 2009: indicators and analysis of the commercial banking sector. Washington D.C.: World Bank.

Swamy, V. (2014). Financial inclusion, gender dimension and economic impact on poor households. World Development, 56, 1-15.

Thabethe, E. (2006, Jan 30). Limpopo workshop on gender and women's economic empowerment strategy. Retrieved from https://www.gov.za/e-thabethe-limpopo-workshop-gender-andwomens-economic-empowerment-strategy\#

Vaill, S. (2003). More than Money: Strategies to build women's economic power (Impact Report No. 1: Economic Opportunity Initiative). San Francisco: The Global Fund for Women.

Witbooi, M., \& Ukpere, W. (2011). Academic Journals Indigenous female entrepreneurship: Analytical study on access to finance for women entrepreneurs in South Africa. African journal of business management, 5, 5646-5657.

World Bank (2014) Global Financial Development Report 2014: Financial inclusion. Washington, D.C.: World Bank. 